\title{
Performance and serum chemistry profile of lambs fed on rations with increasing levels of urea
}

\section{Desempenho e perfil metabólico de cordeiros alimentados com ração contendo níveis crescentes de ureia}

\author{
Diana Rosana Vivian ${ }^{1}$; Américo Fróes Garcez Neto²; José Antônio de Freitas²; \\ Sergio Rodrigo Fernandes ${ }^{3}$; Sandra Rozanski ${ }^{1}$
}

\begin{abstract}
Feed intake and efficiency, animal performance, and protein and energy metabolism were studied in lambs that were fed on increasing levels of urea $(0.0,0.5,1.0$, and $1.5 \%$ of dry matter [DM]). A completely randomized design was used, with four treatments (urea levels) and six replicates. The lambs were fed ad libitum for 56 days until they reached an average body weight of $35 \mathrm{~kg}$. The rations were composed of $34 \%$ Tifton 85 hay (Cynodon spp.) and $66 \%$ concentrate. Crude protein (CP) constituted $17 \%$ of the diet on a dry matter basis, and total digestible nutrients (TDN) accounted for $65 \%$, on average. The dry matter intake (DMI) and crude protein intake (CPI) were not influenced by the urea levels in the diet, presenting average values of 1.175 and $0.206 \mathrm{~kg}_{\text {animal }}{ }^{-1}$ day $^{-1}$, respectively. The average daily gain (ADG), feed conversion ratio (FCR) and gross feed efficiency (GFE) were also not influenced by urea levels $\left(0.225 \mathrm{~kg}_{\text {day }}{ }^{-1}, 5.33 \mathrm{~kg} \mathrm{DM} \mathrm{kg} \mathrm{gain}{ }^{-1}\right.$ and $0.195 \mathrm{~kg}_{\text {gain }} \mathrm{kg} \mathrm{DM}^{-1}$, respectively). Except for urea and glucose concentrations, blood parameters did not change with increasing urea in the diets. The mean values for total protein, albumin, globulin and creatinine in the serum were $7.11 \mathrm{~g} \mathrm{dL}^{-1}, 3.36 \mathrm{~g} \mathrm{dL}^{-1}$, $3.75 \mathrm{~g} \mathrm{dL}^{-1}$ and $0.91 \mathrm{mg} \mathrm{dL}^{-1}$, respectively. Serum urea decreased linearly and serum glucose increased linearly with urea levels in the diet. The addition of $1.5 \%$ of urea to the diets did not change feed intake and efficiency or animal performance, and did not cause metabolic disorders in feedlot lambs in the finishing phase.
\end{abstract}

Key words: Blood. Finishing. Glucose. Nitrogen. Sheep.

\section{Resumo}

Avaliou-se o consumo de alimento, o desempenho animal, a eficiência alimentar, e o metabolismo proteico e energético de cordeiros alimentados com rações contendo níveis crescentes de ureia $(0,0 ; 0,5$; 1,$0 ; 1,5 \%$ da matéria seca - MS). O delineamento foi inteiramente casualizado com quatro tratamentos (níveis de inclusão de ureia) e seis repetições por tratamento. Os cordeiros foram alimentados à vontade por 56 dias até atingirem peso corporal (PC) médio de $35 \mathrm{~kg}$. As rações foram compostas por $34 \%$ de feno de Tifton 85 (Cynodon spp.) e 66\% de concentrado, com 17\% de proteína bruta (PB) e 65\% de nutrientes digestíveis totais (NDT), em média, com base na matéria seca (MS). O consumo de matéria seca (CMS) e de proteína bruta (CPB) não foram influenciados pelos níveis de inclusão de ureia na ração, apresentando valores médios de 1,175 e $0,206 \mathrm{~kg}_{\text {animal }}{ }^{-1} \mathrm{dia}^{-1}$. O ganho médio diário (GMD), a

\footnotetext{
${ }^{1}$ Mestres em Ciência Animal, Universidade Federal do Paraná, UFPR, Setor Palotina, Palotina, PR, Brasil. E-mail: diana.vivian@ agroceres.com; sandra_rozanski@yahoo.com.br

${ }^{2}$ Profs., Departamento de Zootecnia, UFPR, Setor Palotina, Palotina, PR, Brasil. E-mail: americo.garcez@ufpr.br; freitasjaf@ ufpr.br

${ }^{3}$ Pós-Doutorando do Programa de Pós-Graduação em Ciência Animal, UFPR, Setor Palotina, Palotina, PR, Brasil. E-mail: srfernandes83@gmail.com

* Author for correspondence
} 
conversão alimentar (CA) e a eficiência alimentar bruta (EAB) também não foram influenciados pelos níveis de inclusão de ureia e apresentaram valores médios de $0,225 \mathrm{~kg} \mathrm{dia}^{-1}, 5,33 \mathrm{~kg}$ de MS kg de ganho-1 e $0,195 \mathrm{~kg}$ de ganho $\mathrm{kg}$ de $\mathrm{MS}^{-1}$. Com exceção da ureia e da glicose, os metabólitos sanguíneos não foram influenciados pelos níveis de inclusão de ureia na ração. Os valores médios para as concentrações séricas de proteínas totais, albumina, globulinas e creatinina foram $7,11 \mathrm{~g} \mathrm{dL}^{-1}, 3,36 \mathrm{~g} \mathrm{dL}^{-1}, 3,75 \mathrm{~g} \mathrm{dL}^{-1}$ e $0,91 \mathrm{mg} \mathrm{dL}^{-1}$. A ureia sérica apresentou resposta linear decrescente, enquanto a glicose sérica de apresentou resposta linear crescente ao aumento da inclusão de ureia. A inclusão de até 1,5\% de ureia na MS em rações isoproteicas não afeta o consumo de alimento, o desempenho e a eficiência alimentar, e não causa prejuízos metabólicos em cordeiros confinados na fase de terminação.

Palavras-chave: Glicose. Nitrogênio. Ovinos. Sangue. Terminação.

\section{Introduction}

Appropriate nutrition is important in any production system, constituting a critical point in the process, especially when it involves production in feedlots (GONZAGA NETO et al., 2006). In this system, weight gain should be maximized by providing diets with a high energy content and adequate protein to meet the demand of the animals (HADDAD; HUSEIN, 2004). These diets allow for the early slaughter of lambs, reducing the cost of food and making it an economically viable system.

Protein ingredients have the highest cost per unit in the composition of rations (QUINTÃO et al., 2009). Sources of non-protein nitrogen (NPN), such as urea, may have a lower cost than traditional protein sources (such as soybean meal and cotton) for equivalent quantities of nitrogen $(\mathrm{N})$. The $\mathrm{N}$ use efficiency from the NPN sources depends on several factors, including the timing of the release of ammonia, resulting from the hydrolysis of urea, and the presence of energy for microbial protein synthesis in the rumen. In scenarios of high NPN in relation to crude protein $(\mathrm{CP})$ in the diet, and low organic protein fraction (such as amino acids and peptides) that is degradable in the rumen, animal performance can be impaired (PESSOA et al., 2009).

In animal performance studies, it is important to evaluate the intake and digestibility of nutrients, feed conversion ratio and weight gain (PEREIRA et al., 2008). From a nutritional point of view, weight gain is the result of voluntary feed consumption, which determines the quantity of nutrient intake, while digestibility is a secondary factor that is related to the quality of the food (VAN SOEST, 1994). The metabolic challenge imposed by the intensification of animal production has caused an imbalance between the demand for nutrients by the body, the ability to metabolize them and the level of production to be achieved (GONZÁLEZ, 2000). In this context, the characterization of metabolic profiles is useful to evaluate the animal's nutritional status (PEIXOTO; OSORIO, 2007), and enables a more accurate interpretation of the results of production performance in livestock.

The aim of this study was to evaluate the effect of increasing levels of urea in rations on feed and nutrient intake, performance and feed efficiency, and protein and energy metabolism of feedlot lambs in the finishing phase.

\section{Material and Methods}

\section{Experimental protocol}

The research and procedures conducted on animals were in accordance with the Ethical Principles in Animal Experimentation adopted by the Brazilian College of Animal Experimentation (Colégio Brasileiro de Experimentação Animal COBEA) and were approved by the Animal Care and Use Committee (Comitê de Ética no Uso de Animais - CEUA) of the Federal University of Paraná (Universidade Federal do Paraná - UFPR), Palotina Campus, under the protocol number 08/2012-CEUA issued by the Commission.

The experiment was conducted at the Center of Studies in Small Ruminants (Centro de Estudos 
em Pequenos Ruminantes - CEPER) of Palotina Campus of UFPR, located in Palotina, Paraná state, Brazil. Twenty-four Dorper crossbred lambs of 2-5 months old, with a mean \pm standard error (SE) body weight (BW) of $25.0 \pm 0.9 \mathrm{~kg}$, were used. At the beginning of the experiment, the animals were weighed, identified with ear tags and dewormed (Ivermectina $^{\circledR}$ at a dose of $1 \mathrm{~mL} 50 \mathrm{~kg} \mathrm{BW}^{-1}$ subcutaneously). Subsequently, the animals were housed in individual, covered pens with a slatted floor. The pens were $1.5 \mathrm{~m}^{2}$ and contained a water drinker and individual feeder.

The design was completely randomized, with four treatments and six replications. Treatments corresponded to the inclusion of $0.0,0.5,1.0$ and $1.5 \%$ urea in the ration, based on dry matter (DM). Rations were isoproteic, with $17.03 \%$ DM of crude protein $(\mathrm{CP})$ on average (Table 1). The same protein content of rations was maintained while altering the forage:concentrate ratio $(\mathrm{F}: \mathrm{C})$, which ranged from 25:75 to 40:60 (Table 1). Rations were composed on average of $34 \%$ hay DM Tifton 85 (Cynodon spp.) and 66\% DM of protein-energy concentrate, and were formulated in accordance with the recommendations of NRC (1985) to meet the requirements for moderate weight gain (200 g day $\left.^{-1}\right)$. The period of adaptation to the diets was 15 days and the trial period was 56 days.

Table 1. Proportion of ingredients and nutritional composition of rations with increasing levels of urea provided for feedlot lambs in the finishing phase.

\begin{tabular}{|c|c|c|c|c|}
\hline \multirow{2}{*}{ Component $^{\mathrm{I}}$} & \multicolumn{4}{|c|}{ Urea (\% DM) } \\
\hline & 0.0 & 0.5 & 1.0 & 1.5 \\
\hline \multicolumn{5}{|l|}{ Ingredients } \\
\hline Tifton hay $85(\% \mathrm{DM})$ & 36.0 & 40.0 & 34.0 & 25.0 \\
\hline Concentrate (\% DM) & 64.0 & 60.0 & 66.0 & 75.0 \\
\hline PCC $(\% \mathrm{DM})^{\mathrm{II}}$ & 58.0 & 33.5 & 15.0 & 26.0 \\
\hline Soybean hulls (\% DM) & 5.0 & 25.0 & 49.0 & 19.0 \\
\hline Ground corn $(\% \mathrm{DM})$ & 0.0 & 0.0 & 0.0 & 27.5 \\
\hline Mineral premix $(\% \mathrm{DM})^{\mathrm{III}}$ & 1.0 & 1.0 & 1.0 & 1.0 \\
\hline Urea (\% DM) & 0.0 & 0.5 & 1.0 & 1.5 \\
\hline \multicolumn{5}{|l|}{ Nutritional composition } \\
\hline $\mathrm{DM}(\%)$ & 86.70 & 87.90 & 89.50 & 88.52 \\
\hline $\mathrm{CP}(\% \mathrm{DM})$ & 16.85 & 17.01 & 17.17 & 17.07 \\
\hline $\mathrm{EE}(\% \mathrm{DM})$ & 2.29 & 2.24 & 2.24 & 2.63 \\
\hline NDF (\% DM) & 28.55 & 44.75 & 56.63 & 32.71 \\
\hline $\mathrm{Ca}(\% \mathrm{DM})$ & 0.97 & 0.79 & 0.69 & 0.64 \\
\hline $\mathrm{P}(\% \mathrm{DM})$ & 0.46 & 0.35 & 0.27 & 0.36 \\
\hline $\mathrm{Ca}: \mathrm{P}$ & 2.10 & 2.26 & 2.56 & 1.88 \\
\hline TDN (\% DM) & 65.03 & 63.00 & 63.00 & 68.80 \\
\hline $\operatorname{ME}\left(\right.$ Mcal kg DM $\left.^{-1}\right)$ & 2.36 & 2.27 & 2.27 & 2.48 \\
\hline
\end{tabular}

${ }^{\mathrm{I}}$ DM: dry matter; CP: crude protein; EE: ether extract; NDF: neutral detergent fiber; Ca: calcium; P: phosphorus; Ca:P: calcium:phosphorus ratio; TDN: total digestible nutrients; ME: metabolizable energy

${ }^{\text {II }} \mathrm{PCC}$ - pelletized commercial concentrate: $13 \%$ moisture; $18 \% \mathrm{CP} ; 2.5 \% \mathrm{EE} ; 9 \%$ crude fiber $(\mathrm{CF}) ; 10 \%$ ash; $0.15 \% \mathrm{Ca} ; 0.06 \% \mathrm{P}$; $0.05 \% \mathrm{Na} ; 100 \mathrm{ppm}$ antioxidant butylated hydroxytoluene (BHT); 20 ppm Co; 45 ppm Cu; 55 ppm Fe; 10 ppm I; 50 ppm Mn; 0.3 ppm Se; 1000 IU Vit A; 5,800 IU Vit $\mathrm{D}_{3} ; 600$ IU Vit $\mathrm{E}$

III $1.2 \% \mathrm{Mg} ; 13.3 \% \mathrm{Na} ; 1 \% \mathrm{~S} ; 6.5 \%$ P; $16.2 \% \mathrm{Ca} ; 2250$ ppm Mn; 86 ppm Cu; 1400 ppm Fe; 200 ppm Co; 23 ppm Se; 4500 ppm Zn; 177 ppm I; 100,000 IU Vit A; 65,000 IU Vit $\mathrm{D}_{3} ; 60$ IU Vit E. 
The diets were supplied as total mixed ration (TMR) and split into two daily meals (8:00 and 14:00). Hay was cut into particles of approximately $3 \mathrm{~cm}$ in length to improve utilization by the animals and to reduce waste in the feeder. The animals were fed ad libitum in the adaptation period and during the experiment, keeping the orts at $10 \%$ of the amount of feed provided. Adjustments to the amount of ration supplied were performed every five days based on the amount of orts.

The trial period was set by the time required for the animals' final BW to reach $35 \mathrm{~kg}$, on average, which corresponds to the average BW at slaughter for lambs in the region $(30-40 \mathrm{~kg})$. In order to evaluate DM and nutrient intake, performance, and protein and energy metabolism profiles in lambs at the beginning and at the end of the finishing phase, the experimental period was divided into two periods of 28 days (Initial Period: 0-28 days; Final Period: 29-56 days).

\section{Measurements}

The orts of each animal were collected, weighed and stored in plastic bags daily. At the end of each week, composite samples were formed from the orts collected over the previous seven days. Subsamples of composite samples from each week were collected and stored in a freezer at a temperature of $-4^{\circ} \mathrm{C}$. The sub-samples were thawed at the time of the chemical analysis, and representative composite samples of the initial period and the final period were formed and sent for analysis.

Orts samples were dehydrated in a forced ventilation oven at $65^{\circ} \mathrm{C}$ for $72 \mathrm{~h}$, and were subsequently processed in a Wiley knife mill with a $1 \mathrm{~mm}$ mesh sieve. The chemical analysis included the quantification of DM, CP, ether extract (EE) and ash according to the methods proposed by the AOAC (1990), and neutral detergent fiber (NDF) according to the methodology described by Van Soest et al. (1991). From these nutrients, the non-fibrous carbohydrate (NFC) was calculated according to Hall (2000) and total digestible nutrients (TDN) were calculated according to Weiss et al. (1992). Drying, sample processing and chemical analysis were performed at the Laboratory of Animal Nutrition (Laboratório de Nutrição Animal - LANA) of the UFPR, Palotina Campus.

The daily intake of dry matter (DMI), crude protein (CPI), ether extract (EEI), neutral detergent fiber (NDFI) and total digestible nutrients (TDNI) was calculated for each animal as the difference between the amount of DM and nutrients in the feed provided and in the orts. DMI and nutrient intake were expressed in $\mathrm{kg} \mathrm{day}^{-1}$ and $\% \mathrm{BW}$ day $^{-1}$.

Performance of the lambs was evaluated using weight measurements in the initial period and the final period. Weights were measured early in the morning after fasting for $12 \mathrm{~h}$. The total weight gain (WG, $\mathrm{kg}$ ) was calculated as the difference between initial and final BW of lambs in each finishing phase; the average daily gain (ADG, $\mathrm{kg}$ day $^{-1}$ ) was obtained by dividing the WG by the number of days of each period of finishing phase. Feed conversion (FCR, kg DM kg gain ${ }^{-1}$ ) was calculated by the ratio between DMI and ADG; gross feed efficiency (GFE, $\mathrm{kg}$ gain $\mathrm{kg} \mathrm{DM}^{-1}$ ) corresponded to the inverse of the FCR and was calculated as the ratio of ADG to DMI (SANTANA et al., 2012). FCR and GFE were also calculated for each period of finishing phase.

After the lambs were weighed, blood samples were collected to evaluate metabolic profiles. To assess the dynamics of blood metabolites after feeding, blood samples were collected at 0,2 , 4, 8 and $12 \mathrm{~h}$ postprandial. The protocol was: (1) provide the first meal for the lambs after weighing; (2) collect the orts $1 \mathrm{~h}$ after the first meal; (3) after cleaning the feeders (time 0 ), sample the blood at the aforementioned times.

To facilitate the serial blood sampling and reduce the stress to the animals, samples were collected through a catheter applied and fixed on the lambs' necks one day before the weighing, according to the method described by Krehbiel et al. (1995). The catheter was inserted into the jugular vein in the caudal-ventral direction, and after confirming 
its correct position, the needle was removed and a PRN adapter was coupled to the catheter. A saline solution containing heparin (approximately $3 \mathrm{ml}$ ) was applied in the catheter after each sampling to prevent blood clotting and avoid its obstruction.

Blood samples were collected with a $10 \mathrm{~mL}$ syringe, which was the volume of sample collected at each sampling time. After collection, samples were centrifuged for 10 minutes at 3,600 RPM to obtain the serum. After centrifugation, the serum was stored in Eppendorf microtubes $(1.5 \mathrm{ml})$ and was frozen. Serum samples remained frozen until the time of biochemical analyses, which were conducted in the Laboratory of Clinical Analysis of Veterinary Hospital (Laboratório de Análises Clínicas do Hospital Veterinário) of the UFPR, Palotina Campus. Using Labtest ${ }^{\circledR}$ biochemical kits and the semiautomatic biochemical analyzer Quicklab II - Drake, the concentrations in the serum of total protein (colorimetric method of biuret; Ref. No. 99), albumin (colorimetric method of bromocresol green; Ref. No. 19), creatinine (colorimetric method of Jaffé, Ref. No. 96), urea (colorimetric method of urease; Ref. No. 27) and glucose (kinetic method of glucose oxidase; Ref. No. 134) were determined. The serum globulin was calculated as the difference between serum concentrations of total protein and albumin.

\section{Statistical analysis}

Data on the DM and nutrient intake and the lamb's performance were analyzed in a split plot model, in which the plot was characterized by the urea levels in the ration and the subplots corresponded to periods of the finishing phase (initial and final period). The isolated effects of urea levels and period of finishing, as well as the interaction between the two factors, were tested in an analysis of variance (PROC GLM) at 5\% significance level. When the isolated effect of urea levels was significant, regression analysis (PROC REG) until the second order (quadratic) was performed. When the isolated effect of period of finishing was significant, means were compared using $\mathrm{F}$ test. When the interaction between the two factors was significant, regression analysis for levels of urea was carried out within each period of finishing.

Metabolic profile data were analyzed in a splitsplit plot model, in which the plot was characterized by the urea levels in the ration, the subplots were the periods of the finishing phase (initial and final period) and sub-subplots were the times of blood sampling $(0,2,4,8$ and $12 \mathrm{~h}$ postprandial). The isolated effects of urea levels, period of finishing and time of blood sampling, as well as the interactions among the three factors, were tested in an analysis of variance (PROC GLM) at 5\% level of significance. When the isolated effect for urea levels and for period of finishing were significant, the same analysis described above for DM and nutrient intake and performance data were performed. When there was an isolated effect of time of blood sampling, a regression analysis (PROC REG) of the second order (quadratic) was performed. In the case of a significant interaction among the three factors, developments were carried out considering the hierarchy of factors (plot, subplots and sub-subplots), and the same analysis that was applied to isolated effects was performed (QUINN; KEOUGH, 2004). Analyses were performed using the Statistical Analysis System (SAS) version 9.0.

\section{Results and Discussion}

The DMI and the CPI were not affected ( $\mathrm{p}>$ 0.05 ) by urea levels in the ration or the periods of the finishing phase (Table 2), with average values of 1.175 and $0.206 \mathrm{~kg}_{\text {animal }}{ }^{-1}$ day $^{-1}$, respectively. The average values of DMI for all feeds and in both finishing periods met the recommendation of the NRC (1985) for moderate to fast growth rates (1.0 to $1.3 \mathrm{~kg}$ animal ${ }^{-1}$ day $\left.^{-1}\right)$. The DMI can be reduced when the true protein replaced by NPN exceeds $30 \%$ of the total diet $N$ (RINDSIG, 1977). In this study, the maximum level of urea was $1.5 \%$ DM of the feed, which represented $23.3 \%$ of total dietary $\mathrm{N}$. Under these conditions, the DMI of lambs was not reduced. 
Table 2. Mean and standard error of the mean (SEM) for dry matter and nutrient intake by feedlot lambs fed on rations with increasing levels of urea at the beginning and at the end of the finishing phase.

\begin{tabular}{|c|c|c|c|c|c|c|}
\hline \multirow{2}{*}{ Variables $^{\mathrm{I}}$} & \multicolumn{4}{|c|}{ Urea (\% DM) } & \multirow{2}{*}{ Mean (SEM) } & \multirow{2}{*}{ Regression $^{\mathrm{II}}$} \\
\hline & 0.0 & 0.5 & 1.0 & 1.5 & & \\
\hline \multicolumn{7}{|l|}{ Initial period ( $0-28$ days) } \\
\hline DMI $\left(\mathrm{kg} \mathrm{day}^{-1}\right)$ & 1.087 & 1.175 & 1.168 & 1.132 & $1.139(0.033)$ & NS \\
\hline CPI $\left(\mathrm{kg} \mathrm{day}^{-1}\right)$ & 0.191 & 0.205 & 0.202 & 0.198 & $0.199(0.006)$ & NS \\
\hline $\operatorname{EEI}\left(\mathrm{kg} \mathrm{day}^{-1}\right)$ & 0.028 & 0.027 & 0.028 & 0.032 & $0.029(0.001)$ & NS \\
\hline NFDI $\left(k g\right.$ day $\left.^{-1}\right)$ & 0.245 & 0.451 & 0.655 & 0.353 & $0.426(0.035)$ & NS \\
\hline TDNI (kg day $\left.{ }^{-1}\right)$ & 0.753 & 0.760 & 0.742 & 0.777 & $0.758(0.091)$ & NS \\
\hline $\mathrm{DMI}_{\mathrm{BW}}\left(\% \mathrm{BW}\right.$ day $\left.^{-1}\right)$ & 4.13 & 3.91 & 4.07 & 4.02 & $4.04(0.058) \mathrm{a}$ & NS \\
\hline $\mathrm{CPI}_{\mathrm{BW}}\left(\% \mathrm{BW}\right.$ day $\left.^{-1}\right)$ & 0.72 & 0.69 & 0.72 & 0.70 & $0.70(0.009) \mathrm{a}$ & NS \\
\hline $\mathrm{EEI}_{\mathrm{BW}}\left(\% \mathrm{BW}\right.$ day $\left.^{-1}\right)$ & 0.10 & 0.10 & 0.10 & 0.10 & $0.11(0.001) \mathrm{a}$ & NS \\
\hline $\mathrm{NFDI}_{\mathrm{BW}}\left(\% \mathrm{BW}\right.$ day $\left.^{-1}\right)$ & 1.58 & 1.56 & 1.56 & 1.41 & $1.53(0.111)$ & NS \\
\hline $\mathrm{TDNI}_{\mathrm{BW}}\left(\% \mathrm{BW}\right.$ day $\left.^{-1}\right)$ & 2.72 & 2.53 & 2.63 & 2.63 & $2.62(0.035) \mathrm{a}$ & NS \\
\hline \multicolumn{7}{|l|}{ Final period (29-56 days) } \\
\hline DMI $\left(\right.$ kg day $\left.^{-1}\right)$ & 1.199 & 1.213 & 1.240 & 1.189 & $1.210(0.031)$ & NS \\
\hline CPI $\left(\mathrm{kg} \mathrm{day}^{-1}\right)$ & 0.211 & 0.213 & 0.217 & 0.206 & $0.212(0.006)$ & NS \\
\hline EEI $\left(\mathrm{kg} \mathrm{day}^{-1}\right)$ & 0.030 & 0.029 & 0.029 & 0.033 & $0.030(0.001)$ & NS \\
\hline NFDI $\left(\mathrm{kg}\right.$ day $\left.^{-1}\right)$ & 0.228 & 0.483 & 0.676 & 0.336 & $0.428(0.039)$ & NS \\
\hline TDNI (kg day $\left.{ }^{-1}\right)$ & 0.799 & 0.778 & 0.831 & 0.839 & $0.815(0.023)$ & NS \\
\hline $\mathrm{DMI}_{\mathrm{BW}}\left(\% \mathrm{BW}\right.$ day $\left.^{-1}\right)$ & 3.65 & 3.62 & 3.65 & 3.50 & $3.61(0.770) b$ & NS \\
\hline $\mathrm{CPI}_{\mathrm{BW}}\left(\% \mathrm{BW}\right.$ day $\left.^{-1}\right)$ & 0.64 & 0.64 & 0.64 & 0.61 & $0.63(0.014) b$ & NS \\
\hline $\mathrm{EEI}_{\mathrm{BW}}\left(\% \mathrm{BW}\right.$ day $\left.^{-1}\right)$ & 0.09 & 0.09 & 0.09 & 0.10 & $0.09(0.002) b$ & NS \\
\hline $\mathrm{NFDI}_{\mathrm{BW}}\left(\% \mathrm{BW} \text { day }^{-1}\right)^{\mathrm{III}}$ & 0.70 & 1.44 & 1.99 & 0.99 & $1.27(0.112)$ & $* * *$ \\
\hline $\mathrm{TDNI}_{\mathrm{BW}}\left(\% \mathrm{BW} \mathrm{day}^{-1}\right)$ & 2.43 & 2.43 & 2.56 & 2.48 & $2.47(0.047) b$ & NS \\
\hline
\end{tabular}

${ }^{\mathrm{I}}$ DMI: dry matter intake; CPI: crude protein intake; EEI: ether extract intake; NDFI: neutral detergent fiber intake; TDNI: total digestible nutrients intake; $\mathrm{DMI}_{\mathrm{BW}}$ : $\mathrm{DMI}$ relative to body weight $(\mathrm{BW}) ; \mathrm{CPI}_{\mathrm{BW}}$ : $\mathrm{CPI}$ relative to $\mathrm{BW} \mathrm{EEI}_{\mathrm{BW}}$ : $\mathrm{EEI}$ relative to $\mathrm{BW}$; $\mathrm{NFDI}_{\mathrm{BW}}$ : NFDI relative to $\mathrm{BW}$; TDNI $\mathrm{BW}_{\mathrm{BW}}$ : TDNI relative to $\mathrm{BW}$

IINS: not significant; $* \mathrm{p}<0.05 ; * * \mathrm{p}<0.01 ; * * * \mathrm{p}<0.0001$

III $\mathrm{NDFI}_{\mathrm{BW}}=0.6334+2.8921 \mathrm{U}-1.7382 \mathrm{U}^{2}\left(\mathrm{R}^{2}=0.9000\right)$

Means for the same variable followed by different letters in the same column differ according to $F$ test $(p<0.05)$.

The NDF intake showed a quadratic relationship $(\mathrm{p}<0.05)$ with urea $(\mathrm{U})$ levels in the rations (NDF $\left.=0.2126+0.9260 \mathrm{U}-0.5475 \mathrm{U}^{2} ; \mathrm{R}^{2}=0.8806\right)$, regardless of the period of finishing. The NDF intake is related to the NDF of rations, which were 28.55 , $44.75,56.63$ and $32.71 \% \mathrm{DM}$ for rations with 0.0 , $0.5,1.0$ and $1.5 \% \mathrm{DM}$ of urea, respectively (Table 1). The maximum value of $0.665 \mathrm{~kg} \mathrm{DM}_{\text {animal }}{ }^{-1}$ day $^{-1}$ for NDF was observed in the ration with $1.0 \%$ DM of urea, which showed higher NDF among the evaluated diets.

To make isoproteic rations, it was not possible to keep the NDF and the F:C constant in the evaluated diets (Table 1). Among the concentrate ingredients used in the formulations, soybean hulls were added at levels of $5-49 \%$ of the feed DM, with a maximum value of inclusion in the ration with $1.0 \% \mathrm{DM}$ urea. As soybean hulls have approximately $60 \%$ DM of $\mathrm{NDF}$, they were initially considered as an option to replace forage in the diet (RESTLE et al., 2004). However, due to the high digestibility of NDF, the soybean hulls provide high production of short chain fatty acids, which has positive effects on animal performance (BACH et al., 1999). In addition to the high digestibility of NDF, soybean hulls have high pectin content. According to the NRC (2001), pectin represents $62.4 \%$ of the fraction of nonfiber carbohydrates (NFC) of soybean hulls, and its cell wall has little lignin, which maximizes the 
use of structural carbohydrates by microorganisms. Pectin differs from starch by the axial position of the carbon four bond, so that it is not attacked by digestive enzymes but it is susceptible to microbial action (MORGADO et al., 2009). In addition to not producing lactic acid during fermentation, the structure of pectin (monosaccharide galacturonic acid) promotes an efficient buffering of the rumen through its cation exchange capacity and links with metal ions (VAN SOEST et al., 1991). Thus, it can be inferred that the use of soybean hulls contributed to the avoidance of a reduction in DMI with the inclusion of urea in feed, which may be related to the timing of degradation of NPN and carbohydrate by rumen microorganisms. Other factors related to the soybean hulls that may explain the constant DMI in relation to the increase in NDF are reduced particle size and high hydration capacity of this ingredient. These features help to increase the passage rate of NDF through the gastrointestinal tract, resulting in no change to DMI (IPHARRAGUERRE; CLARK, 2003).

The DMI, CPI, EEI and TDNI in relation to BW were not affected $(p>0.05)$ by urea levels in the diet, but were higher $(p<0.05)$ in the initial period of the finishing phase (Table 2). The decrease in DMI and nutrient intake in relation to BW was expected, because as the lambs grow, their metabolic rate decreases, causing a decrease (proportional to BW) in the requirement of DM intake and nutrients to meet the demand for maintenance and growth.

There was quadratic effect of urea levels in the ration $(p<0.05)$ on the NDF in relation to the $B W$ $\left(\mathrm{NDFI}_{\mathrm{BW}}\right)$ at the final period of the finishing phase
(Table 2). As with the NDF, differences in NDF and the $\mathrm{F}$ : $\mathrm{C}$ of the rations explain the quadratic response of $\mathrm{NDFI}_{\mathrm{BW}}$ for urea levels at the final period of the finishing phase.

The performance of the lambs and feed efficiency traits were not affected $(\mathrm{p}>0.05)$ by urea levels in the ration (Table 3). Other studies also showed no effect of increasing levels of urea in the diet on the ADG and FCR in lambs (OKAMOTO et al., 2008; ZIGUER et al., 2012). Mean values for ADG, FCR and GFE were $0.225 \mathrm{~kg} \mathrm{day}^{-1}, 5.33 \mathrm{~kg}$ DM kg gain ${ }^{-1}$ and $0.195 \mathrm{~kg}_{\text {gain }} \mathrm{kg} \mathrm{DM}^{-1}$, respectively. The ADG was within the range indicated by the NRC (1985) for lambs showing moderate to fast growth rates, implying that the ADG results obtained in this study were satisfactory.

Except for WG and FCR, traits showed higher values at the final period of finishing (Table 3) when compared with the same traits at the initial period. The highest ADG and GFE values at the end of the finishing phase indicated a better use of urea by lambs during this period. The hydrolysis rate of urea in the rumen decreases over time (OWENS; ZINN, 1993), meaning that there may be a decrease in animal performance for about one month, then a return to normal growth rates after this adaptation period.

With the exception of serum urea and glucose, blood metabolites were not affected $(\mathrm{p}>0.05)$ by urea levels in the ration. The average values for serum total protein, albumin, globulins and creatinine were $7.11 \mathrm{~g} \mathrm{dL}^{-1}, 3.36 \mathrm{~g} \mathrm{dL}^{-1}, 3.75 \mathrm{~g} \mathrm{dL}^{-1}$ and $0.91 \mathrm{mg} \mathrm{dL}^{-1}$, respectively. 
Table 3. Mean and standard error of the mean (SEM) for performance and feed efficiency traits of feedlot lambs fed on rations with increasing levels of urea at the beginning and at the end of the finishing phase.

\begin{tabular}{|c|c|c|c|c|c|c|}
\hline \multirow{2}{*}{ Variables $^{\mathrm{I}}$} & \multicolumn{4}{|c|}{ Urea (\% DM) } & \multirow{2}{*}{ Mean (SEM) } & \multirow{2}{*}{ Regression $^{\text {II }}$} \\
\hline & 0.0 & 0.5 & 1.0 & 1.5 & & \\
\hline \multicolumn{7}{|l|}{ Initial period ( $0-28$ days) } \\
\hline Final BW (kg) & 30.70 & 30.10 & 31.50 & 31.00 & $30.82(1.005) b$ & NS \\
\hline WG $(\mathrm{kg})$ & 4.88 & 5.97 & 5.53 & 6.52 & $5.72(0.253)$ & NS \\
\hline $\mathrm{ADG}\left(\mathrm{kg} \mathrm{day}^{-1}\right)$ & 0.188 & 0.199 & 0.185 & 0.231 & $0.201(0.010) b$ & NS \\
\hline FCR $\left(\right.$ kg DM kg gain $\left.{ }^{-1}\right)$ & 5.40 & 5.64 & 6.39 & 5.07 & $5.64(0.238)$ & NS \\
\hline GFE $\left(\mathrm{kg}\right.$ gain $\left.\mathrm{kg} \mathrm{DM}^{-1}\right)$ & 0.174 & 0.188 & 0.157 & 0.204 & $0.181(0.008) b$ & NS \\
\hline \multicolumn{7}{|l|}{ Final period (29-56 days) } \\
\hline Final BW (kg) & 36.10 & 36.50 & 36.50 & 36.90 & $36.50(1.005) \mathrm{a}$ & NS \\
\hline WG $(\mathrm{kg})$ & 5.43 & 5.52 & 5.10 & 5.90 & $5.49(0.244)$ & NS \\
\hline $\operatorname{ADG}\left(\mathrm{kg} \mathrm{day}^{-1}\right)$ & 0.247 & 0.251 & 0.232 & 0.268 & $0.249(0.022) \mathrm{a}$ & NS \\
\hline FCR (kg DM kg gain $\left.{ }^{-1}\right)$ & 4.93 & 5.01 & 5.47 & 4.64 & $5.01(0.203)$ & NS \\
\hline GFE $\left(\mathrm{kg}\right.$ gain $\left.\mathrm{kg} \mathrm{DM}^{-1}\right)$ & 0.208 & 0.212 & 0.188 & 0.223 & $0.208(0.009) \mathrm{a}$ & NS \\
\hline
\end{tabular}

${ }^{\mathrm{I}} \mathrm{BW}$ : body weight; WG: weight gain; ADG: average daily gain; FCR: feed conversion ratio; GFE: gross feed efficiency

II NS: not significant; $* \mathrm{p}<0.05 ; * * \mathrm{p}<0.01 ; * * * \mathrm{p}<0.0001$

Means for the same variable followed by different letters in the same column differ according to $\mathrm{F}$ test $(\mathrm{p}<0.05)$.

Table 4. Mean and standard error of the mean (SEM) for serum concentrations of blood metabolites determined at 0-12 hours after feeding in feedlot lambs fed on rations with increasing levels of urea at the beginning and at the end of the finishing phase.

\begin{tabular}{|c|c|c|c|c|c|c|}
\hline \multirow{2}{*}{ Variables } & \multicolumn{5}{|c|}{ Postprandial time (hours) } & \multirow{2}{*}{ Mean (SEM) } \\
\hline & 0 & 2 & 4 & 8 & 12 & \\
\hline \multicolumn{7}{|l|}{ Initial period (0-28 days) } \\
\hline Total protein $\left(\mathrm{g} \mathrm{dL}^{-1}\right)^{\mathrm{I}}$ & 8.14 & $8.70 \mathrm{a}$ & $6.56 \mathrm{~b}$ & 5.43 & $7.31 \mathrm{a}$ & $7.23(0.16)$ \\
\hline Albumin $\left(\mathrm{g} \mathrm{dL}^{-1}\right)^{\Pi 1}$ & $3.96 \mathrm{a}$ & $4.08 \mathrm{a}$ & 3.65 & 3.24 & $3.03 \mathrm{~b}$ & $3.59(0.07) \mathrm{a}$ \\
\hline Globulins $\left(\mathrm{g} \mathrm{dL}^{-1}\right)^{\mathrm{III}}$ & $4.18 \mathrm{~b}$ & 4.63 & $2.91 \mathrm{~b}$ & 2.20 & $4.28 \mathrm{a}$ & $3.64(0.14)$ \\
\hline Creatinine $\left(\mathrm{mg} \mathrm{dL}^{-1}\right)$ & $0.86 \mathrm{~b}$ & $0.78 \mathrm{~b}$ & 0.94 & 0.83 & $0.80 \mathrm{~b}$ & $0.84(0.01) b$ \\
\hline Urea $\left(\mathrm{mg} \mathrm{dL}^{-1}\right)$ & 54.83 & 79.04 & 58.96 & 49.04 & 54.38 & $59.25(1.50) b$ \\
\hline Glucose $\left(\mathrm{mg} \mathrm{dL}^{-1}\right)$ & 82.90 & 91.92 & 95.88 & 90.67 & 80.19 & $88.31(1.33) \mathrm{a}$ \\
\hline \multicolumn{7}{|l|}{ Final period (29-56 days) } \\
\hline Total protein $\left(\mathrm{g} \mathrm{dL}^{-1}\right)^{\mathrm{I}}$ & 7.94 & $7.27 \mathrm{~b}$ & $7.47 \mathrm{a}$ & 5.62 & $6.47 \mathrm{~b}$ & $6.98(0.12)$ \\
\hline Albumin $\left(\mathrm{g} \mathrm{dL}^{-1}\right)^{\mathrm{II}}$ & $2.57 \mathrm{~b}$ & $2.70 \mathrm{~b}$ & 3.50 & 3.19 & $3.66 \mathrm{a}$ & $3.13(0.05) b$ \\
\hline Globulins $\left(\mathrm{g} \mathrm{dL}^{-1}\right)^{\mathrm{III}}$ & $5.37 \mathrm{a}$ & 4.56 & $3.97 \mathrm{a}$ & 2.42 & $2.80 \mathrm{~b}$ & $3.85(0.13)$ \\
\hline Creatinine $\left(\mathrm{mg} \mathrm{dL}^{-1}\right)^{\mathrm{IV}}$ & $1.17 \mathrm{a}$ & $0.96 \mathrm{a}$ & 0.98 & 0.94 & $0.85 \mathrm{a}$ & $0.98(0.02) \mathrm{a}$ \\
\hline Urea $\left(m g \mathrm{dL}^{-1}\right)$ & 70.52 & 73.57 & 56.96 & 56.02 & 56.63 & $62.74(1.09) \mathrm{a}$ \\
\hline Glucose $\left(\mathrm{mg} \mathrm{dL}^{-1}\right)$ & 83.82 & 61.00 & 70.50 & 73.76 & 74.93 & $72.71(1.51) \mathrm{b}$ \\
\hline $\begin{array}{l}{ }^{\mathrm{I}} \mathrm{TP}_{\text {INITIAL }}=8.832-0.741 \mathrm{U}+ \\
\mathrm{TP}_{\text {FINAL }}=8.091-0.403 \mathrm{U}+ \\
{ }^{\mathrm{II}} \mathrm{ALB}_{\text {INITIAL }}=4.0594-0.090 \\
\mathrm{ALB}_{\text {FINAL }}=2.5857+0.160 \\
\mathrm{III}_{\text {FII }} \mathrm{GLOB}_{\text {INITIAL }}=4.759-0.64 \\
\mathrm{GLOB}_{\text {FINAL }}=5.505-0.563 \\
{ }^{\text {IV }} \mathrm{CREAT}_{\text {FINAL }}=1.0867-0.0 \\
\text { Means for the same variable }\end{array}$ & $\begin{array}{l}=0.6570) \\
0.7450) \\
99) \\
2\left(\mathrm{R}^{2}=0.72\right. \\
\left(\mathrm{R}^{2}=0.62\right. \\
\left(\mathrm{R}^{2}=0.96\right. \\
7073) \\
\text { ifferent lett }\end{array}$ & & & & & \\
\hline
\end{tabular}


Serum urea decreased linearly $(\mathrm{p}<0.05)$ with the inclusion of urea in the ration (Urea $=64.37-4.21 \mathrm{U}$; $\left.\mathrm{R}^{2}=0.6878\right)$. Whereas microorganisms correctly use ammonia $\left(\mathrm{NH}_{3}\right)$ when there is adequate energy intake, increasing the proportion of carbohydrate sources with high degradation rates in the feed with higher levels of urea (1.0-1.5\% DM; Table 1) may result in a better use of $\mathrm{NH}_{3}$ for microbial protein synthesis. This may explain the decrease in serum urea with increasing urea levels in the ration. The greater availability of energy could be due to the increased proportion of soybean hulls in diets with 0.5 and $1.0 \% \mathrm{DM}$ of urea, and the inclusion of maize in the diet with $1.5 \% \mathrm{DM}$ of urea. The highest level of serum urea was found in lambs fed rations without the addition of urea, which may be attributed to the use of low fermentation potential sources in the commercial concentrate.

The serum glucose increased linearly $(p<0.05)$ with the inclusion of urea in the ration (Glucose $=$ $\left.77.57+4.42 \mathrm{U} ; \mathrm{R}^{2}=0.9228\right)$. A similar result was reported by Noro et al. (2012) when evaluating the effects of three levels of urea in feed $(0.00,0.55$ and $1.28 \mathrm{~g} \mathrm{~N} \mathrm{~kg}$ of metabolic weight $^{-1}$ ) on the energy metabolism of lambs. The authors attributed the higher glucose levels in lambs fed on a diet with high NPN to high phosphoenolpyruvate carboxykinase (PEPCK) enzyme activity in the liver, which plays an important role in hepatic gluconeogenesis process. It is likely that in the present study there was an increase in the gluconeogenic capacity of the liver with increasing inclusion of urea in the ration, resulting in increased blood glucose in lambs.

Serum total protein showed a quadratic response $(p<0.05)$ at the sampling times at the beginning and at the end of the finishing phase (Table 4). Serum concentrations of this metabolite remained within the reference range for this species in the sampling times (6.0-7.9 $\mathrm{mg} \mathrm{\textrm {dL } ^ { - 1 } )}$ (KANEKO et al., 2008). Variations in serum total protein among sampling times, and between the periods of finishing, may be related to changes that occur in the animal as it modifies the composition of gain as the finishing phase progresses. It is likely that in the first period, there was a higher protein demand for muscle deposition. Therefore, urea was efficient in the synthesis of microbial protein, which ensured adequate levels of amino acids. This did not cause metabolic disorders because the protein is mainly synthesized in the liver in order to ensure its contribution to other tissues.

Serum albumin decreased linearly $(\mathrm{p}<0.05)$ at sampling times in the initial period of finishing, and exhibited a quadratic effect at the sampling times in the final period of finishing (Table 4). The serum albumin was maintained at values close to the reference for this species (2.4-3.0 $\mathrm{g} \mathrm{dL}^{-1}$ ) (KANEKO et al., 2008), with higher values at the sampling times 0 and $2 \mathrm{~h}$ in the initial period of finishing (3.96 and $4.08 \mathrm{~g} \mathrm{dL}^{-1}$, respectively; Table 4).

Serum globulins showed a quadratic response ( $\mathrm{p}$ $<0.05$ ) with the sampling times in the two periods of the finishing phase (Table 4). There was no effect of urea levels on this metabolite, implying that urea did not suppress the immune system. The variation in serum globulins during fasting may be related to the variation in water intake during this period (RUSSELL; ROUSSEL, 2007).

Serum creatinine decreased linearly $(p<0.05)$ over the sampling times in the final period of finishing (Table 4). The average values for serum creatinine at the beginning and end of the finishing phase remained slightly below the reference range for sheep (1.2-1.9 $\mathrm{mg} \mathrm{dL}^{-1}$ ) (KANEKO et al., 2008), which is justified by the lower muscle development of lambs compared to adult animals. Creatinine is formed during the activity of skeletal muscle and is used as an index for the glomerular filtration rate, and as with urea, a reduction in glomerular filtration increases the serum creatinine (MEYER et al., 1995). Therefore, the higher serum creatinine at the beginning of the sampling period may be related to the metabolism of nutrients in the muscle and the excretion of metabolites from muscle after feeding. 


\section{Conclusion}

The inclusion of up to $1.5 \% \mathrm{DM}$ of urea in isoproteic diets did not significantly affect the DM intake, performance or feed efficiency of lambs during the finishing phase, which justifies its use in order to reduce production costs. Serum concentrations of metabolites related to protein and energy metabolism remained within acceptable ranges for sheep, suggesting that the inclusion of up to $1.5 \% \mathrm{DM}$ of urea in rations does not cause metabolic damage to young sheep.

\section{Acknowledgments}

The authors acknowledge the contribution of Luciana Helena Kowalski during experimental preparation and data collection and Tiago Machado dos Santos in the analysis procedures in LANA of UFPR, Palotina Campus.

\section{References}

ASSOCIATION OF OFFICIAL ANALYTICAL CHEMISTS - AOAC. Official methods of analysis. $15^{\text {th }}$ ed. Arlington: AOAC International, 1990. $1117 \mathrm{p}$.

BACH, A.; YOON, I. K.; STERN, M. D.; JUNG, H. G.; CHESTER-JONES, H. Effects of type of carbohydrate supplementation to lush pasture on microbial fermentation in continuous culture. Journal of Dairy Science, Madison, v. 82, n. 1, p. 153-160, 1999.

GONZAGA NETO, S.; SILVA SOBRINHO, A. G.; ZEOLA, N. M. B. L.; MARQUES, C. A. T.; SILVA, A. M. A.; PEREIRA FILHO, J. M.; FERREIRA, A. C. Características quantitativas da carcaça de cordeiros deslanados Morada Nova em função da relação volumoso:concentrado na dieta. Revista Brasileira de Zootecnia, Viçosa, MG, v. 35, n. 4, p. 1487-1495, 2006.

GONZÁLEZ, F. H. D. Indicadores sanguíneos do metabolismo mineral em ruminantes. In: GONZÁLEZ, F. H. D.; BARCELLOS, J.; PATINÕ, H. O.; RIBEIRO, L. A. Perfil metabólico em ruminantes: seu uso em nutrição e doenças nutricionais. Porto Alegre: Gráfica da Universidade Federal do Rio Grande do Sul, 2000. p. 31-51.

HADDAD, S. G.; HUSEIN, M. Q. Effect of dietary energy density on growth performance and slaughtering characteristics of fattening Awassi lambs. Livestock Production Science, Amsterdam, v. 87, n. 2-3, p. 171177, 2004.

HALL, M. B. Neutral detergent-soluble carbohydrates. Nutritional relevance and analysis. Gainesville: University of Florida, 2000. 77 p.

IPHARRAGUERRE, I. R.; CLARK, J. H. Review: soyhulls for dairy cows. Journal of Dairy Science, Madison, v. 86, n. 4, p. 1052-1073, 2003.

KANEKO, J. J.; HARVEY, J. W.; BRUSS, M. L. Clinical biochemistry of domestic animals. $6^{\text {th }}$ ed. San Diego: Academic Press, 2008. 916 p.

KREHBIEL, C. R.; BRITTON, R. A.; HARMON, D. L.; WESTER, T. J.; STOCK, R. A. The effects of ruminal acidosis on volatile fatty acid absorption and plasma activities of pancreatic enzymes in lambs. Journal of Animal Science, Champaign, v. 73, n. 10, p. 3111-3121, 1995.

MEYER, D. I.; COLES, E. H.; RICH, L. J. Medicina de laboratório veterinário: interpretação e diagnóstico. São Paulo: Roca, 1995. 308 p.

MORGADO, E. S.; ALMEIDA, F. Q.; SILVA, V. P.; GOMES, A. V. C.; GALZERANO, L.; VENTURA, H. T.; RODRIGUES, L. M. Digestão dos carboidratos de alimentos volumosos em equinos. Revista Brasileira de Zootecnia, Viçosa, MG, v. 38, n. 1, p. 7-81, 2009.

NATIONAL RESEARCH COUNCIL - NRC. Nutrient requirements of sheep. $6^{\text {th }}$ ed. Washington: National Academy Press, 1985. 99 p.

Nutrient requeriments of dairy cattle. $7^{\text {th }}$ rev. ed. Washinton: National Academy Press, 2001. 381 p.

NORO, M.; BERTINAT, R.; YANEZ, A.; SLEBE, J. C.; WITTEWER, F. Non-protein nitrogen supplementation increases gluconeogenic capacity in sheep. Livestock Science, Amsterdam, v. 148, n. 3, p. 243-248, 2012.

OKAMOTO, F.; COSTA, R. S.; CUNHA, E. A.; BUENO, M. S.; SILVIA JÚNIOR, J. S.; SILVA, M. A.; SANTOS, L. E. Desempenho de borregas santa inês suplementadas com mistura múltipla com níveis crescentes de ureia em substituição ao farelo de soja. Boletim da Indústria Animal, Nova Odessa, v. 65, n. 4, p. 323-327, 2008.

OWENS, F. N.; ZINN, R. Protein metabolism of ruminants. In: CHURCH, C. D. The ruminant animal: digestive physiology and nutrition. New Jersey: Waveland Press, 1993. p. 227-249.

PEIXOTO, L. A. O.; OSÓRIO, M. T. M. Perfil metabólico proteico e energético na avaliação do desempenho reprodutivo em ruminantes. Revista Brasileira de Agrociência, Pelotas, v. 13, n. 3, p. 299-304, 2007. 
PEREIRA, O. G.; SOUZA, V. G.; VALADARES FILHO, S. C.; PEREIRA, D. H.; RIBEIRO, K. G.; CECON, P. R. Consumo e digestibilidade dos nutrientes e desempenho de bovinos de corte recebendo dietas com diferentes níveis de ureia. Ciência Animal Brasileira, Goiânia, v. 9, n. 3, p. 552-562, 2008.

PESSOA, R. A. S.; LEÃO, M. I.; FERREIRA, M. A.; VALADARES FILHO, S. C.; VALADARES, R. F. D.; QUEIROZ, A. C. Balanço de compostos nitrogenados e produção de proteína microbiana em novilhas leiteiras alimentadas com palma forrageira, bagaço de canade-açúcar e ureia associados a diferentes suplementos. Revista Brasileira de Zootecnia, Viçosa, MG, v. 38, n. 5, p. 941-947, 2009.

QUINN, G.; KEOUGH, M. Experimental design and data analysis for biologists. Cambridge: University Press, 2004. 537 p.

QUINTÃO, F. A.; PÉREZ, J. R. O.; SALVADOR, F. M.; SIQUEIRA, G. B.; GERASEEV, L. C. Desempenho de borregas Santa Inês alimentadas com duas fontes de nitrogênio não proteico em dietas formuladas estimulando a síntese de proteína microbiana ruminal. Ciência e Agrotecnologia, Lavras, v. 33, n. 1, p. 279-284, 2009.

RESTLE, J.; FATURI, C.; ALVES FILHO, D. C.; BRONDANI, I. L.; SILVA, J. H. S.; KUSS, F.; SANTOS, C. V. M.; FERREIRA, J. J. Substituição do grão de sorgo por casca de soja na dieta de novilhos terminados em confinamento. Revista Brasileira de Zootecnia, Viçosa, MG, v. 33, n. 4, p. 1009-1015, 2004.

RINDSIG, R. B. Practical dairy goat feeding. Dairy Goat Journal, Upper Darby, v. 55, n. 1, p. 12-19, 1977.
RUSSELL, K. E.; ROUSSEL, A. J. Evaluation of the ruminant serum chemistry profile. Veterinary Clinics of North America: Food Animal Pratice, Maryland Heights, v. 23, n. 3, p. 403-426, 2007.

SANTANA, M. H. A.; ROSSI JUNIOR, P.; ALMEIDA, R.; CUCCO, D. C. Feed efficiency and its correlations with carcass traits measured by ultrasound in Nellore bulls. Livestock Science, Amsterdam, v. 145, n. 1-3, p. 252-257, 2012.

VAN SOEST, P. J. Nutritional ecology of ruminant. $2^{\text {th }}$ ed. London: Comstock Publishing Associates, 1994. 476 p.

VAN SOEST, P. J.; ROBERTSON, J. B.; LEWIS, B. A. Methods for dietary fiber, neutral detergent fiber, and no starch polysaccharides in relation to animal nutrition. Journal of Dairy Science, Madison, v. 74, n. 10, p. 35833597, 1991.

WEISS, W. P.; CONRAD, H. R.; St. PIERRE, N. R. A theoretically-based model for predicting total digestible nutrient values of forages and concentrates. Animal Feed Science and Technology, Philadelphia, v. 39, n. 1-2, p. 95-110, 1992.

ZIGUER, E. A.; ROLL, V. F. B.; BERMUDES, R. F.; MONTAGNER, P.; PFEIFER, L. F. M.; DEL PINO, F. A. B.; CORREA, M. N.; DIONELLO, N. J. L. Desempenho e perfil metabólico de cordeiros confinados utilizando casca de soja associada a diferentes fontes de nitrogênio não-proteico. Revista Brasileira de Zootecnia, Viçosa, MG, v. 41, n. 2, p. 449-456, 2012. 
